\title{
18. Turning into a Gardiya
}

Stephen Muecke

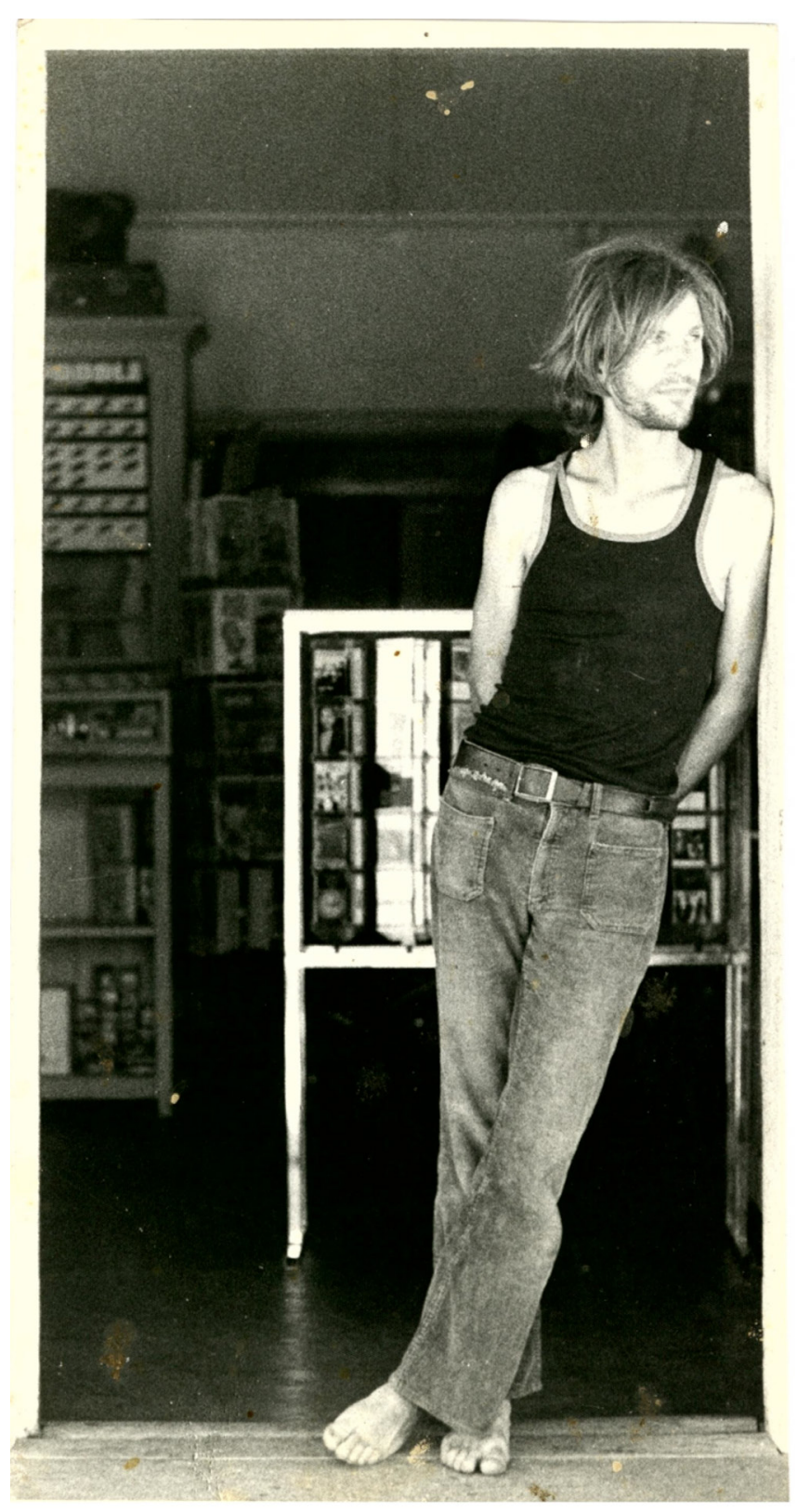

Stephen Muecke, Chinatown. 
Well, it was a long time ago nowwhen I was in Halls Creek-

I'd been there a few times-

different times,

coming and going, you know-

bits of research, this and that-

Or sometimes I was just passing through-

that good old country, you know-

I couldn't keep away!-

Well, anyway, this one time-

there's some kind of ceremony going on-

that time the camping ground was just north of the highway-

right in town-

nothing there now-

just servos there today-

all those humpies musta been pulled down-

you know, cleaning up the town-

Archie Singpoo had had a few-

but he was still in control-

says, 'I can cut you, if you want?' -

looking at me up close, grinning-

oh, he had the authority and everything-

he'd told me about how his uncle-

used to run the business around here-

down to Balgo, back up through Nicholson station west to Christmas Creekand back again to Halls Creek-

'I know one gardiya got that' -

I say-

'that Kim Akerman, you know him?-

cicatrices across his chest-

might be that Wongai mob down in Kalgoorlie bin cut-im' -

(I was talking Pidgin, you know-

just to fit in-

your language slips around like that-

Anyway, that's another story I'll tell you later-

about researching Aboriginal English)

I wasn't sure-

'What for-?

how you gonna cut me?'- 
'Longa didjun' -

Archie says-

grabs one empty stubbie-

stone right there for break-im-

'Oh! No, no,' I say-

'I think not right-

not really right for me-

gardiya and everything' -

I was just a youngfella, then-

didn't want to be 'scarred for life'!-

Tracey Moffatt, I think, had a photo series-

called Scarred for Life-

wonderful photos of Koori and Murri kids-

adolescents-

being punished for this or that-

wondering how they fit in-

Oh, Archie knew what he was doing, you know-

even if we'd done the run-

down to the pub-

brought back a slab of Emu Bitter-

and that ceremony still going on-

people drinking-

I felt shame-

He was fitting me in-

simple as that-

(loud) 'Alright,' he says-

'I gonna call you "brother" -

I'm tjungarrayi, that mean you gotta be tjungarrayi, too-

and that woman you with?-

You gotta call her nambitjin, wife-

Straight. That's the Law-

the Law-

that one over there too,' pointing with his lips-

and all the guys sitting around have a good laugh-

that old girl-

not young, she really old!-

one oldfella sitting next to me whispering, 'he like-em gardiya, that old girl, oh yes, any kine' - 
So, that's the finish, of my story-

'bout how I got made into a gardiya-

well, not really the finish-

I got a lotta story like that-

different ways-

but finish now, I gotta go back to Sydney-

Because there's another Stephen Muecke who isn't a gardiya, who works at the uni, writes lots of weird stuff. It is a question of style-I want to argue the point, and I can't do that in Paddy Roe's narrative style (Roe 1983) that I have just been reproducing, respectfully-you have to shift your language if you want move your argument along and take it somewhere where it does seem to matter. There are no new thoughts without some kind of new style, as Nietzsche said (Nietzsche 1996, p. 342). And there is a geography as well, styles have their regions and countries; if I started in a Kimberley English style, it is because it belongs up there, just as this kind of English belongs to other places, pretty universal, maybe not academic, and if I get too colloquial the editors have to reject it. Regional Englishes that belong in their places, then, that seem to thrive and not disappear because the teachers in primary say 'stop talking that mixedup English!' No, the smart students just acquire another language; they are all multilingual, and why not?

In Sydney there are no gardiya. You might be a gubba, just as in the Top End you are a balanda, and there must be many other names for whitefellas. So I can't become a gardiya unless I cross the invisible border into the Kimberley. And I do each time I go there, just like all the other whitefellas who have been given a place in Indigenous Australia that they are more or less aware of, more or less accepting of. They are, in fact, more or less assimilated. This is no trivial thing. It is a powerful connection, creating, without any pressure, the kind of loyalty that normally goes with family.

'Teeb, Teeb!' -

kids in the bushes outside pub-

'Teeb, teeb' -

Until I realise it's my name-

they are calling-

(yelling) 'Tomorrow-

we gotta go la riber!'-

When you got that-

Toyota-

you a driver-

for anyone- 
And if one day you-

take a mob of kids-

swimming la river-

lotta fun, cute kids-

singing aaall the way-

That Creedence:

Don't go around tonight, Well, it's bound to take your life, There's a bad moon on the rise. ${ }^{1}$

Cute alright-

But lotta humbug goin' on-

Turning into a gardiya. Metamorphosis is the ancient philosophy of this country: that range of hills is always becoming a woman lying down is always becoming a blue-tongue lizard (Muecke 2004, p. 4). What if metamorphosis, and everything that it implies about the interrelatedness and persistence of life forms, were as rational as any other system?

I can sing you that song-

if you like?-

Nalyak-

that blue-tongue lizard-

If you turn into a gardiya you can turn back again, soon as you head south. Don't even try to talk straight! Because speech turns, like good stories, talk has to take a detour to get somewhere. You don't become fully Aboriginal, any more than that mob becomes whitefella when you call them names.

Let's not get sentimental about being a gardiya, it can be killer work if you are hired to administer or teach in some remote community. 'Kartiya are like Toyotas', Kim Mahood reports a Western Desert woman saying. 'When they break down we get another one' (Mahood 2012). There are 'the mad, the bad and the incompetent' (the classic 'missionaries, mercenaries and misfits'), as well as the well-meaning idealists who get ground down by the isolation and pressures. For these ones, Mahood's tough account is required reading. And in her story, the new admin. woman is happily inducted as a nampitjin (my 'wife' by the way), meaning she can only 'belong' to a certain section of the community: 'She doesn't understand that she is colonised territory. Invisible to her, power struggles of ancient lineage and epic proportions are being played out. This is our kartiya-hands off.'

1 I didn't realise it at the time. Poverty stricken kids singing joyously about strange fears sweeping across the country: 'I know the end is coming soon/I fear rivers overflowing/I hear the voice of rage and ruin'. 
One other time-

I was starting my PhD work-

running around looking for stories-

just like this one I guess!-

This would be, ooh-

late 70s?-

and I start in Broome-

oh, I'd been there before-

before, plenty of time-

in and out of there-

stayed six weeks one time-

that time I was working for Susan Kaldor-

and Ann Davidson was my offsider-

on language stuff-

You know what I was saying just now?-

those primary school teachers-

couldn't understand why kids-

couldn't talk that High English-

you know-

they didn't have an ear for that Creole-

teachers never understand-

teachers back in those days, anyway-

Alright, so I'm looking for Paddy Roe-

coupla people said he was good for story-

even old Prof Berndt from UWA-

I was a student there then-

few other people-

So I find him-

in the middle of Broome-

he's right there-

oh, I had to go to mamabulandjin first-

and they sent me on-

he's at the old Anne St Reserve-

that time-

working-

oh, it was-

just about before dinner time- 
And I asked him if he can help me with story-

'What's that?' he yells out-

he's on toppa the roof-

with crowbar and everything-

pulling off the old iron-

corrugated iron-

you know, that one got $\mathrm{ramu}^{2}$

'What kine?' -

he climbs down from the roof-

shakes my hand and everything-

'University, eh? Down in Perth-

jus' story and all that kinda thing-

you want me to tell-im story?-

oh, I can do that!-

no worries, young fella-

bye ' $\mathrm{n}$ ' bye-

might be after tea time?' -

then he looks at me straight-

'things gotta go both ways, you know' -

I didn't understand-

'They closin' this reserve-

all my old people gotta move-

most of them gone now-

(lifts a gnarled finger) I'm only one man here (laughs)-

so I'm taking this all stuff Block-

Coconut Well-

millibinyari we call-im-

So I gotta take all this old iron out there-

you can give me a hand?-

alright, chuck-im that lot longa truck-

I only got this truck coupla day-

then yunmi can drive out there-

tell story-

(under his breath) two ways, you know.'

Who said economies were just about cold hard cash? People get traded too, and that fine storytelling had me seduced, seconded and permanently attached to the Roe mob.

2 This gardiya building material has an aesthetic that crosses over. The corrugations are like the parallel grooves incised in old boomerangs and shields. 
Position description:

Driver.

Minder for old Butcher Joe (back then).

Official paperwork.

Scholarship: numerous articles and two books for Paddy Roe.

What's my name? Paddy calls me 'Madya' (boss).

Economics is about entanglement. Philosopher and anthropologist Bruno Latour highlights what a mad construction economics is, that pride and joy of us westerners and our most powerful export. It is providence itself, a second nature, a religion that presides over the distribution of all that is good and evil. For the sake of comparison, Latour talks of anthropologists who might read Marcel Mauss on the gift and look at 'primitive' economies in the Pacific and 'recoil in horror at the imbroglios which are described among these others, "Oh dear", they sigh, "these poor people will never get out of this mess, they are always tied up, attached, indebted, hooked, mixed up, entangled."' Whereas, Latour goes on, in our modern economies 'with long practice we have gotten used to being hardened to the idea of settling up with those we enter into transactions with ... we get out of such imbroglios by adding the exact opposite: "And now we are even; I owe you nothing; we have exchanged the equivalent; see you later!"' (Latour 2012, pp. 446-447, my translation).

An ideal of turning someone close into a stranger, of wanting to close deals, as if getting away were the aim, But in fact people don't live to the ideal and this economy, that sees itself also as a hard science where equivalent values are precisely and coldly calculated, is just as mixed up and intimate as any Pacific bartering system. And the cold hard gaze? Far from it, it is full of sales surprises and marketing tricks, testosterone and stimulant-fueled traders, fictional goods, cooked books and outright lies.

My first son was named for Butcher Joe-

Joe Muecke-

1983, he was born-

in Adelaide-

I musta gone back to the town I was born-

pick up a nice Adelaide girl!-

So that connection was always there, after that, crossing over into my familyOne of my old relatives might have got a bit of a shock-

(What? They called him after a black man?)

but we never worry-

me and Patience-

we never worry-

very happy when that beautiful little boy come along- 
Joe, like Butcher Joe, like Joseph Roe-

All gumbali, namesakes -

Now, that gumbali-

here's the thing-

when you are namesake for someone-

that's a special relationship-

not like brother-in-law or granny or cousin-brother

but a little bit the same-

You not a straight-up relation through family-

oh you might be, but-

you share something different with your gumbali-

like every time I go to Broome-

when I head up there-

I might see Stephen Albert-

you know, Baamba, the actor?

he used to be in the bands too, playing music -

Broome Beats, singing-

he was in Bran Nue Dai as well, Uncle Tadpole-

Anyway, he always says hello to me-

walkin' round Chinatown-

'Hey, Gumbali!' -

we have a chat-

some sort of relationship we got-

I don't know what it is, but!

And when me and Patience went back to Broome-

after Joe was born-

this might been-

oooh-

nineteen-eighty-five or -six?-

we had that little boy with us-

only one kid then-

We was down at mulabulandjin-

came along to see old Lulu3

a bit too early in the morning I think-

he was still in the house-

so we waited-

Teresa had some puppies-

and little Joe was playing around with the puppies-

I got a photo of that somewhere-

33 Paddy Roe's family nickname. 
When Lulu come out of the house-

he was all happy-

you know like he is -

full of energy-

he calls out 'HELLO!' -

with his arms out wide-

and little Joe ran and jumped into his arms-

straight away-

soon as he called him-

and that was the first time he ever met Lulu-

you know-

it's a thing like that-

So having been magically captured ('colonised' as Mahood said) this one gardiya, me, is still a loyal member of the Goolarabooloo mob, still working for Paddy's grandsons 40 years later. In the Land of Metamorphoses, you get possessed by psychogenic forces. You begin to understand that economics is about trading values, it's not just accumulation for profit's sake, surely? If it is not about things that really matter to you, what is the point? Another idea that Latour gets from Gabriel Tarde: What if 'to have' were more important than 'to be'? So you can philosophise about having or not having, as you are being possessed by country, as much as by its custodians. This is philosophically miles away from being about identity or being. So 'being' a gardiya is about having tradable values. You have certain ideas, skills, know-how, attached to you, and you are attached to them, they matter to you. So when you become in turn attached to some mob, they have these values too, on call. And from them the gardiya gets knowledge, skills, know-how. Two ways.

So that is why, in these stories about metamorphosis and 'skill transfer' as they say in the jargon, I have wanted to stress how lives are at stake, with the refrain of CCR's old song in my head, that the kids sang all those years ago, reminding us about the 'rage and ruin' spreading across the country. That can happen, sure, if too many people don't ask themselves what really matters to them. 


\section{References}

Latour B, 2012, Enquête sur les Modes d'Existence: Une anthropologie des modernes, La Découverte, Paris.

Mahood, K 2012, 'Kartiya Are Like Toyotas: White workers on Australia's cultural frontier', Griffith Review, vol. 36.

Muecke, S 2004, Ancient and Modern: Time, culture and Indigenous philosophy, UNSW Press, Kensington.

Nietzsche, F 1996, Human, All Too Human, translated by R J Hollingdale, Cambridge University Press, Cambridge.

Roe, P 1983, Gularabulu: Stories from the West Kimberley, (edited and with an introduction by S Muecke), Fremantle Arts Centre Press, Fremantle. 
This text taken from Ngapartji Ngpartji: In turn in turn:

Ego-histoire, Europe and Indigenous Australia

Edited by Vanessa Castejon, Anna Cole, Oliver Haag and Karen Hughes,

published 2014 by ANU Press, The Australian National University, Canberra, Australia. 